\title{
People's Perceptions of the Telangana Issue: A Study with Reference to the Perceptions of Students
}

\author{
Dr.M. Yaznasri Manikarnika \\ Faculty Member, Department of Mass Communication \& Journalism, Yogi Vemana University \\ Kadapa, Andhra Pradesh
}

\begin{abstract}
The issue of Telangana is as old as human memory continues to remain intact. Telangana comprising ten districts was an integral part of Nizam State. Though India attained independence, the people of Telangana were forced to be under the tyrannical rule of Nizam. Only with patel's intervention through the army action Telangana became an integral part of Indian Union. Subsequently Telangana was merged with Andhra State leading to the formation a United Andhra Pradesh. Ever since its merger, the people of Telangana started raising their voice for the formation a separate State of Telangana.
\end{abstract}

The paper highlights all the developments that took place till the formation of Telangana State on $2^{\text {nd }}$ June 2015.

Keywords: Telangana, perception agitation, participation, Indian Union Razakars, Operation polo, Mulki Common language.

\section{INTRODUCTION}

The word "Telangana" has attracted the ample attention of the people not only of Andhra Pradesh but also the entire country and across the globe as well. The Telangana issue, therefore, continues to be discussed, debated and analyzed by people belonging to all the sections of society on the one hand and by the institutions- political and social, on the other. Perhaps in the political history of India there has never been such an issue raised with intensity of this kind as the Telangana issue today. The role played by students and electronic media is very significant in intensifying the movement for a separate state of Telangana. Hence it is pertinent to analyze about the coverage of Telangana issue in different television channels and perceptions of people in general and students in particular about the coverage of this issue in various television channels. This thesis sifts different facets of Telangana movement with special focus on how it is covered in electronic media and what perceptions the students have about this coverage.

\section{HistoricAL IMPORTANCE OF TELANGANA}

Telangana is one of the three regions of Andhra Pradesh. It was ruled by the Nizams of Hyderabad before it became a part of Indian Union. When India became independent from the British Empire, the Nizam of Hyderabad wanted Hyderabad State to remain independent under the special provisions given to princely states (Rao, D.V., 1988). Rebellion has started throughout the state against the Nizam rule and his army known as Razakars. Razakars led by its chief, Qasim Razvi. massacred myriad people and rebels to suppress the movement, but became a fiasco. Razakars destructed many temples and monuments throughout the state. Many mass massacres took place similar to Jallianwalabhag, throughout the state. The Government of India annexed Hyderabad State on September 17, 1948, in an operation by the Indian Army called Operation Polo. When India became independent, the Telugu-speaking people were distributed in about 22 districts, 9 of them in the Telangana region of Nizam's Dominions (Hyderabad State), 12 in the Madras Presidency (Andhra region) and one in French-controlled Yanam. A communist led peasant revolt started in 1946 and lasted until 1951, weaning the viability of Hyderabad as an Indian state in its present form.

Central Government appointed a civil servant Vellodi Narayana Menon, K., as First Chief Minister of Hyderabad State on 26th January 1950. He administered the state with the help of bureaucrats from the states of both Madras and Bombay. In 1952, Telangana had tasted democracy for the first time when it participated in general elections and elected Dr. Burgula Ramakrishna Rao as the Chief 
Minister of Hyderabad State. The period between 1952 and 1956 can be described as the happiest period for the people of Telangana (Keshav Rao Jadhav, 1997).

\section{Formation of ANDHRa State}

The Telugu speaking people in Madras state enjoyed some form of democracy since 1920. During this time there were violent Mulki agitations by some Telanganites to send back bureaucrats from Madras state' and to strictly implement Mulki rules. Meanwhile Telugu-speaking areas (Andhra region) were carved out of an erstwhile Madras state by popular agitation of leaders like Potti Sri Ramulu to create Andhra State with Kurnool as its capital in 1953.

\section{Merger of Telangana AND Andhra}

In December 1953, the States Reorganization Commission was appointed to prepare for the creation of states on linguistic lines. The States Reorganization Commission (SRC) was not in favour of an immediate merger of Telangana region with Andhra state, albeit the common language between the two.

Paragraph 382 of States Reorganization Commission (SRC) said "opinion in Andhra is overwhelmingly in favour of the larger unit; public opinion in Telangana has still to crystallize itself. Important leaders of public opinion in Andhra themselves seem to appreciate that the unification of Telangana with Andhra, though desirable, should be based on a voluntary and willing association of the people and that it is primarily for the people of Telangana to take a decision about their future". The people of Telangana had several concerns. The region had a less developed economy than Andhra, but with a larger revenue base (mostly because it taxed rather than prohibited alcoholic beverages), which people of Telangana feared might be diverted for use in Andhra. They also feared that planned irrigation projects on the Krishna and Godavari rivers would not benefit Telangana proportionately even though people of Telangana controlled the headwaters of the rivers. It was also feared that the people of Andhra, who had access to higher standards of education under the British Rule, would have an unfair advantage in seeking Government and Educational jobs.

The commission proposed that the Telangana region be constituted as a separate state with a provision for unification with Andhra state, after the 1961 general elections, if a resolution could be passed in the Telangana state assembly with a two-third majority. The Chief Minister of Hyderabad State, Burgula Ramakrishna Rao, opined that a majority of Telangana people were against the merger. Prime Minister Jawaharlal Nehru initially was skeptical of merging Telangana with the Andhra State, fearing a "tint of expansionist imperialism" in it (Rao, K.V.N., 1972). Later he compared the merger to a matrimonial alliance having "provisions for divorce" if the partners in the alliance cannot get on well. However following the "Gentlemen's Agreement, the central government established a unified Andhra Pradesh on November 1, 1956. The agreement provided reassurances to Telangana in terms of power sharing as well as administrative domicile rules and distribution of expenses of various regions. Anti-Nehru politics emerged with the repression of the Telangana movement and many within the Congress extended their hands to radical and not-so-radical leftist causes.

\section{Favourable Movements in Favour of Separate State for Telangana}

The movement for separate state of Telangana took place in different Phases-predominantly in 1952, 1969, 1997, 2001, 2004, 2009 and 2011.

\subsection{Mulki Agitation (1952)}

The demand to preserve the identity of the region with the creation of a separate state started immediately after independence in reaction to the treatment meted out to Hyderabad by the central government. People thought that their socio-economic conditions would improve after the integration of the region into the Indian union. But they were disappointed and disillusioned with the administration. "After Police Action, officials were brought here from the coastal districts and the districts of the then Madras Presidency, for administrative convenience". These officials displayed a condescending attitude towards the local people and treated Hyderabad as an occupied territory. N.M.Jaisoorya who was a Member of Parliament in the early 1950s from Hyderabad noted, "People have been looted apart from being oppressed and insulted by the outside officials". This behaviour led to an agitation against non-mulkis (outsiders) in August 1952. The agitation known popularly as the 'mulki' movement lasted for over one month. Students from all over the region actively participated in the movement which was suppressed by the authorities. The 1952 agitation is significant because it shaped the attitude of the people towards the issue of state reorganization (Kodandaram, M., 2007). 


\subsection{Movement of 1969}

Soon after the formation of Andhra Pradesh state, people of Telangana expressed dissatisfaction over how the agreements and guarantees were made and implemented. Discontent with the 1956 Gentleman's Agreement intensified in January 1969, when the guarantees that had been agreed upon were supposed to be lapsed. Student agitation for the continuation of the agreement began at Osmania University in Hyderabad and spread to other parts of the region. Government employees and opposition members of the State Legislative Assembly swiftly threatened "direct action" in support of the students.

Although the Congress faced some dissensions within its ranks, its leadership stood against additional linguistic states. As a result, defectors from the Congress, led by M. Chenna Reddy, founded the Telangana Praja Samithi. In Parliament elections held in May 1971, Telangana Praja Samithi (TPS) won 10 out 14 Parliament seats in Telangana. Despite electoral successes, however, some of the new party leaders gave up their agitation in September 1971 after realizing that Prime Minister is not inclined towards Telangana, much to the chagrin of separatists, rejoined the safer political haven of the Congress ranks.

\subsection{Jai Andhra Movement}

At the end of 1972, when the Supreme Court upheld the Mulki rules, the very next day of the Judgment, Jai Andhra movement was started in Coastal Andhra and Rayalaseema regions protesting the protections mentioned in the Gentleman's Agreement. P. V. Narasimha Rao had to resign as Chief Minister of Andhra Pradesh on January 10, 1973. President's rule was imposed in the State. Finally a political settlement was arrived at under the aegis of the Central Government. A Six-Point Formula was agreed upon by the leaders of the two regions to prevent any recurrence of such agitations in future. The "Six-Point Formula' included (1) the abolition of Mulki rules and the Telangana Regional Committee (protections mentioned in the Gentleman's Agreement) and (2) the establishment of a Central University at Hyderabad to augment educational facilities and (3) In regard to jobs, state was divided into six zones, within the framework of three regions, namely, Coastal Andhra, Rayalaseema, and Telangana (Zone V, and Zone VI) with Hyderabad under Zone VI. Each zone should prefer local candidates for state government jobs. However according to GOM, the regions were rezoned with Zone I, II, III Coastal Andhra, Zone IV Rayalaseema, Zone V and VI Telangana.

\subsection{Movement in 1990s}

The emotions and forces of pent up feelings generated by the movement in 1969 drived for a separate state until 1990s when Bharatiya Janata Party (BJP), promised a separate Telangana state if they came to power. BJP created Jharkhand, Chhattisgarh and Uttarkhand states in year 2000 as promised. But the BJP could not create a separate Telangana state because of the opposition from its coalition partner, Telugu Desam Party. These developments brought a new life into the separatist Telangana movement by 2000. In another development, a new party called Telangana Rashtra Samithi TRS), led by Kalvakuntla Chandrasekhar Rao (KCR), was formed in 2001 with the single point agenda of creating a separate Telangana state with Hyderabad as its capital.

\section{Grievances of Telangana Proponents}

Telangana is the largest single region of the three regions of Andhra Pradesh state covering 41.47 per cent of its total area is inhabited by 40.54 per cent of the state's population, contributes about 76 per cent to the state's revenues (excluding central government contribution). From Central Govt: 19.86 per cent, From Telangana: 61.47 per cent (including $37.17 \%$ from Hyderabad), From Andhra: 14.71, From Rayalaseema: 3.90 per cent.

Among others, alleged injustices in water, budget allocations, and jobs are the grievances cited by Telangana proponents. Telangana supporters cite that the majority of water supply is from the Telangana region, yet canal irrigation disproportionately benefits the Coastal Andhra region with relative underdevelopment of Telangana. In addition, the share of education funding for Telangana ranges from 9.86 per cent in government aided primary schools to government degree colleges which has a share of 37.85 per cent. Above numbers include the expenditure in Capital Hyderabad. In addition, budget allocations to Telangana are generally less than 1/3 of total Andhra Pradesh budget. In addition, there are allegations that the Telangana budget is being misappropriated. Telangana proponents cite that only 20 per cent of total Government employees, less than 10 per cent employees 
in secretariat, less than 5 per cent of head of the departments in Andhra Pradesh are from Telangana, while those from other regions make up the bulk of employment. Andhra Pradesh was represented by Telangana Chief Ministers for only 6-1/2 years out of over five decades of its existence, with no Chief Minister from the region being in power continuously for more than 2-1/2 years. By establishing hegemony over the state the Andhra elite could divert resources to their region (Kodandaram, M., 2007). The process of development has been disrupted ironically by the policies pursued by successive governments of Andhra Pradesh. Jaya Shankar (2004) presented how Telangana has been subjected to injustice in various fields.

Proponents of a separate Telangana state felt that all the agreements, accords, formulas, plans and assurances on the floor of legislature and Lok Sabha, in last 50+ years, could not be honoured and Telangana was forced to remain neglected, exploited and backward. They alleged that the experiment to remain as one state proved to be a futile exercise and therefore, separation is found to be the best solution.

\section{Elections AND Alliances in 2004}

In 2004, for Assembly and Parliament elections, the Congress party and the TRS had an electoral alliance in the Telangana region with the promise of a separate Telangana State. Congress came to power in the state and formed a coalition government at the centre. TRS joined the coalition government in 2004 and was successful in making a separate Telangana state a part of the Common Minimum Program (CMP) of the coalition government. In September 2006, TRS withdrew support from the Congress led coalition government at the centre on the grounds of alleged indecision by the government over the delivery of its electoral promise to create Telangana.

In December 2006, the TRS won the by-election to the Karimnagar parliamentary constituency with a record margin. The TRS continued to pressure for the creation of Telangana state in 2008.

All TRS Legislators in Parliament and in the State (4 MPs, 16 MLAs and 3 MLCs) resigned in the 1st week of March 2008 and forced by-elections to increase the pressure on Congress party to take immediate action on Telangana.

By-elections for the 16 MLA seats and 4 MP seats were held in May 29, 2008. During the election campaign, the TRS party said it is a referendum on a Telangana state but both Congress and TDP parties said it is not a referendum on Telangana and also said that they are not opposed to the formation of Telangana state. To the disappointment of Telangana proponents, the TRS retained only 7 out of 16 MLA seats and 2 out of 4 MP seats in the by-elections.

In June 2008, Devender Goud, who is considered number two in the TDP, a Polit Bureau member and Deputy Leader of the Telugu Desam Legislature Party, resigned from the party saying he would devote his time and energy to the formation of a separate Telangana state. In July 2008, Mr. Goud along with some other leaders like Mr.E.Peddi Reddy formed a new party called Nava Telangana Praja Party or NTPP. On 9th October 2008, in a historical turnaround from its 26-year history TDP announced its support for the creation of Telangana.

\section{A Landmark Year-2009}

In February 2009, the state government declared that it had no objection, in principle, to the formation of separate Telangana and that the time had come to move forward decisively on this issue. To resolve issues related to it the government constituted a joint house committee.

Ahead of the 2009 General Elections in India, all the major parties in Andhra Pradesh supported the formation of Telangana. The Congress Party still says it is committed to Telangana statehood,, but claims Muslim minorities are opposed to creation of separate state along with majority of people. Some analysts, however, feel that the "Muslim reluctance card" has been deftly played by the then Chief Minister, Y. S. Rajasekhara Reddy, who is staunchly opposed to the formation of the new state.

The Telugu Desam Party (TDP) had promised to work for Telangana statehood. Telangana Rashtra Samithi (TRS) joined a Mahakutami (or grand alliance) with TDP and left parties to defeat the Congress party for denying statehood for Telangana. The Praja Raj yam Party (PRP), newly founded by film star Chiranjeevi, opposed Telangana statehood. Nava Telangana Party merged with TDP after it realization that there is no enough political space for two sub-regional Telangana parties with Telangana statehood as the main agenda. 
On November 29, 2009, the TRS president, K. Chandrashekar Rao (KCR) started a fast-unto-death demanding that the Congress party introduce a Telangana bill in the Parliament. He was arrested by the government of Andhra Pradesh. Student organizations, employee unions and various organizations joined the movement. The apparent decline in KCR's health led to a sense of urgency to take a decision on the issue of Telangana statehood.

\section{Declaration of Telangana State and Aftermath}

On December 9, 2009, P. Chidambaram, the Union Minister of Home Affairs announced that the Indian government would start the process of forming a separate Telangana state, pending the introduction and passage of a reparation resolution in the Andhra Pradesh assembly. KCR thus ended his 1 day fast, saying from his hospital bed that this was a "true victory of the people of Telangana."

Pro-Telangana supporters celebrated the central government decision while those from the Coastal Andhra and Rayalaseema regions (Andhra region) protested out and out. In fact, within a short time of the Home Minister's declaration, sensing the public mood, MLAs from the Coastal Andhra and Rayalaseema regions (Andhra region) submitted their resignations in protest of the process of creation of a new state within Andhra Pradesh. By the 16th of December, at least 147 legislators (including Praja Raj yam Founder Chiranjeevi) and many Members of Parliament had resigned in protest of the Government's decision to begin discussions on forming a new state of Telangana. Later 22 Ministers from the State Cabinet, all from Andhra (Coastal Andhra and Rayalaseema) regions submitted their resignations.

On December 23, the Government of India announced that no action on Telangana will be taken until a consensus is reached in all the parties. A committee with retired judge Justice Srikrishna has been appointed to study the nitty-gritty of the situation in the state of Andhra Pradesh and find the feasibility with reasonable need to create separate statehood to Telangana.

\subsection{Srikrishna Committee Report}

The five-member Committee was announced by the Home Ministry on February 3, 2010 this year as part of the Centre's move to have wide-ranging consultations with all the sections of the people and all political parties and groups in Andhra Pradesh on the emotive issue. The Committee had been asked to submit its report by December 31, 2010.

Apart from Mr. Justice Srikrishna, the other members of the committee were Dr. Ranbir Singh, ViceChancellor of the National Law University, Delhi, Dr. Abusaleh Shariff, Senior Research Fellow, International Food Policy Research Institute, Delhi, Dr. (Ms) Ravinder Kaur, Professor, Department of Humanities and Social Sciences, Indian Institute of Technology (IIT), Delhi and Mr. Vinod K. Duggal, former Union Home Secretary, who was the Member-Secretary.

The Committee was asked to examine the situation in Andhra Pradesh with reference to the demand for a separate State of Telangana as well as the demand for maintaining the present status of a United Andhra Pradesh. It was also asked to review the developments in the state since its formation and their impact on the progress and development of the different regions of the State.

In an all-party meeting on 6 January 2011 released the 505-page Srikrishna Committee Report. The report discusses six solutions to the problem. The preferred option is keeping the State united by simultaneously providing certain definite constitutional and statutory measures for socio-economic development and political empowerment of Telangana region through the creation of a statutorilyempowered Telangana Regional Council. The second best option is Bifurcation of the State into Telangana and Seemandhra as per existing boundaries, with Hyderabad as the capital of Telangana and Seemandhra to have a new capital.

\subsection{Non-Cooperation Movement and Million March}

Noncooperation movement was started on 17th February 2011 which lasted for 16 days with participation by 300,000 government employees. It caused a loss of Rs. 8 billion per day in revenue to government. In February and March, Assembly session was boycotted for weeks and Parliament session was boycotted for several days by Telangana representatives.

Million March was organized by Telangana JAC in Hyderabad on 10f March 2010. In a move to disrupt the march, police arrested over thousand activists throughout the region and closed down entry to Hyderabad city by topping certain transportation services and diverting traffic. Around 50,000 people reached the venue of the march, Tank Bund by hoodwinking police. Some Telangana activists 
damaged 16 statues of personalities hailed from Seema-Andhra representing Telugu culture and language. They threw some of the remnants into the lake. Top leaders of all political parties in the state and various cultural organizations brutally condemned the venomous vandalism.

\subsection{Mass Resignations}

Fearing law and order problem due to severe violence similar to the Million March incident, State police refused to give permission to TRS to hold their formation day public meeting in Parade grounds in Hyderabad. The state government sanctioned Rs.75 lakh for repairing and re-installation of statues on Tank Bund, demolished during the Million March programme. Along with installation of the 16 statues, another new statue of social activist from Telangana, Komaram Bheem, would also be installed. Both TJAC and the Telangana Congress leaders set fresh deadlines to renew their agitation. On 4th July 2011 as many as 81 of 119 Telangana MLAs in the state, 12 out of 15 Telangana Ministers in state, 13 out of 17 Telangana MPs in Lok Sabha, 1 Rajya Sabha MP(Congress) and 20 MLCs resigned protesting delay in the formation of Telangana. On 20th July, 30-year-old Yadi Reddy was found dead 100 yards from Parliament House in Delhi. An eight-page suicide note says the young driver from greater Hyderabad region of Telangana was upset over the government not creating a new state for his homeland. The speaker of the AP assembly on 23 July summarily rejected the resignations of all 101 MLAs citing that they were made in an emotionally surcharged atmosphere.

\section{SEPTEMBER 2011 - PRESENT}

\subsection{All Peoples Strike / Sakala Janula Samme}

On 12th September 2011, a day before Sakala Janula Samme (All people's strike), TRS organized a public meeting in Karimnagar which was attended by lakhs of people including Telangana JAC leaders, BJP and New Democracy party leaders. Starting on 13th September, as part of 'strike by all sections of people' supporting Telangana statehood, government employees throughout Telangana stayed out of work affecting government offices throughout the region and vowed to continue it till the formation of Telangana state. Lawyers boycotted courts and 60,000 coal miners of Singareni Collieries (SCCL Ltd.) also joined the strike. On 14th and 15th September, nearly 450 movie theaters in Telangana were closed by the call given by Telangana film chamber. Starting on 16th September, government teachers joined the strike. Private school managements declared one day holiday in support of the strike. On 19th September, the employees of state road transport corporation and electricity board employees in Telangana joined the indefinite strike.

"The rail rokho programme at various places in the city became a conglomeration of various facets of the Telangana culture. With music, dance, plays and a sumptuous lunch, Manoharabad railway station, one of the hotspots, wore the look of a weekly fair". - The New Indian Express

On a call given by JAC, road blockades on national highways throughout Telangana, the rail blockade by JAC and the strike of auto rickshaw union on 24th September and on 25th disrupted transport services. Virtually all sections of people joined this strike. On 30th September, as the strike entered 18th day, even while Congress central leadership meeting several Telangana congress leaders, JAC called a bandh in Hyderabad city. On 2nd October, JAC leaders, employee unions' leaders and TRS leaders including KCR met Prime minister to explain the grave situation in Telangana due to the strike and asked to expedite the decision on the statehood demand' The strike has resulted in an unprecedented power crisis in the state. On 4th October, only $223 \mathrm{MU}$ of power generated against the demand of $275 \mathrm{MU}$ impacting both the industry and agriculture.

"There is no need to continue the strike as their opinion over Telangana is received already by Congress high command and the Centre" pined the Andhra Pradesh Chief Minister Sri Nallari Kiran Kumar Reddy.

\section{Students' Role in Telangana Movement}

Throughout the period of separate Telangana agitation the intensity was always caused by the participation of students of Osmania University and Kakatiya University. In December 1968 the students of Osmania University organized a rally to protest against discrimination in government jobs against Telangana people. Keshav Rao Jadhav and Sudershan Singh, both teachers, supported the students. Discontent intensified when some of the guarantees agreed upon were supposed to lapse in January 1969. Student agitation for the proper implementation of the guarantees began at Osmania University in Hyderabad and spread to other parts of the region like wildfire. 
To fulfill their cause and in order to make their presence felt, a separate body in the name of Telangana students joint action committee was formed so as to mount pressure upon all the political parties not to dilute their demand for a separate statehood. In order to bring their strong demand for a separate statehood for the notice of central leaders of all the political parties, they conducted a series of agitation programs like dharnas, raastha rokhos, bandhs and fast unto death.

While student politics in Andhra Pradesh is mostly a conglomerated caste-based affair, the wholehearted involvement of students from all sections in the latest upsurge on the demand for a separate Telangana is a new development. In fact, Telangana students surprised the Telangana Rashtra i (TRS) which is spearheading the movement since 2001 itself when they rose in unison in support of K.Chandrasekhara Rao who announced his fast-unto-death for a separate Telangana, and staged violent protests when he arrested before he could start the fast. As KCR's fast entered the eighth fey on Sunday, the government has concerned about his health as it is about fe volatile situation the students have created in the 10 districts of Telangana region. And, like in 1969, when students got involved in the movement, the epicenter of the uprising this time is the Osmania University in the state capital.

In fact, it is the students' agitation that has brought the Telangana movement back into the limelight, even if KCR's fast was the trigger. "Till KCR broke his fast momentarily the pro-Telangana students' protests were in his support. Then things changed dramatically and drastically and students took the lead which was unprecedented," says TRS ideologue Prof K Jaishankar.

\section{REFERENCES}

[1] Akhileswari, R., (1997). "A Bloodied Telangana : A Narrative", In : Telangana, Dimensions of Under development, (Eds.) S. Simhadri and P.L. Vishweswar Rao, Centre for Telangana Studies, Hyderabad.

[2] Anjaiah, S. (2010). The Role of Telangana Middle Classes in Integration of the State in Indian Union, Statehood for Telangana, Ed. K.Y.Reddy, Deccan Telangana, Hyderabad.

[3] Balaswamy, B., (2006). Communications for Sustainable Development,

[4] Concept Publishing Company, New Delhi.

[5] Bharathbhushan, M.(2009), Telangana Imbroglio, In : Bharath Bhoosham, M.Venugopal, (Eds.) "Telangana :The State of Affairs", AdEd Value Ventures, Hyderabad.

[6] Chalapathi Rau, M. (1974), The Press, National Book Trust, India.

[7] Devid Winterson, (2010). "T.V. Journalism Skills, Tools and Techniques", Centrum Press, New Delhi.

[8] Duncan B Forrester, (2009) Sub-regionalism in India: A Cast Study of

[9] Telangana, In: Bharathbhushan, M.Venugopal, (Eds.) “Telangana :The State of Affairs “, AdEd Value Ventures, Hyderabad.

[10] Gopal Reddy, G., Harihara Sharma, T., Govinda Raju Chakradar (Eds.) (2003), Racahana Journalism Kalasala, Hyderabad. 